\title{
The Burns Menace: Antibiotics for the Fight against Burns Bacterial Infection, a Systemic Review
}

\author{
Pius Agbenorku1, Richcane Amankwa², Manolo Agbenorku3 ${ }^{3}$, Nana Yaa Odamea Asare 4 \\ ${ }^{1}$ Reconstructive Plastic Surgery \& Burns Unit, Department of Surgery, Komfo Anokye Teaching Hospital, Kwame Nkrumah \\ University of Science \& Technology, Kumasi, Ghana \\ ${ }^{2}$ Department of Clinical Microbiology, School of Medical Sciences, Kwame Nkrumah University of Science \& Technology, \\ Kumasi, Ghana \\ ${ }^{3}$ Department of Medicine, Komfo Anokye Teaching Hospital, Kumasi, Ghana \\ ${ }^{4}$ Department of Trauma \& Orthopaedics, Komfo Anokye Teaching Hospital, Kumasi, Ghana \\ Email: pimagben@yahoo.com, amarichcane2006@yahoo.com, manolo2agb@gmail.com, sweetsisterny@yahoo.co.uk
}

How to cite this paper: Agbenorku, P., Amankwa, R., Agbenorku, M. and Asare, N.Y.O. (2016) The Burns Menace: Antibiotics for the Fight against Burns Bacterial Infection, a Systemic Review. Surgical Science, 7, 532-538.

http://dx.doi.org/10.4236/ss.2016.712071

Received: September 12, 2016

Accepted: December 25, 2016

Published: December 28, 2016

Copyright $\odot 2016$ by authors and Scientific Research Publishing Inc. This work is licensed under the Creative Commons Attribution International License (CC BY 4.0).

http://creativecommons.org/licenses/by/4.0/

\section{Abstract}

Burn wound infection delays wound healing, leading to varying degrees of morbidity and mortality. Various antibiotics are administered to burn patients in burn wound management. The emergence of antibiotic resistance is a menace that costs families and the country. This review seeks to expound on infections related to burn wounds, common bacteria of burn wound infections and choice of antibiotics in burns treatment. Words such as burns, wound infection, burns injury and antibiotics were put into the Google search engine. Only articles related to the subject of burns, burn wound infection and antibiotics were used to write the review. Articles obtained included case reports on burns, research articles, review articles, short notes, briefs, literatures and other articles relating to burns. We found that the choice of antibiotics in the management of burns is an issue of major concern due to the evolution of pathogens causing these infections. The challenge of antibiotic resistance still persists in burns wound management. The commonly used topical antimicrobials included silver sulphadiazine, silver nitrate solution, silver impregnated dressings and mafenide acetate. Mafenide acetate has a wide antibacterial activity and also acts against the usual wound pathogens that were identified: Pseudomonas aeruginosa and Staphylococcus aureus. The role of antibiotic resistance is of major concern. Antibiotics must be administered after culture evidence in order to reduce the chance of increasing evolution of resistant strains of bacteria. 


\section{Keywords}

Burn Wounds, Burn Patients, Infection, Antibiotic, Morbidity, Mortality

\section{Introduction}

Burns are regarded as one of the common forms of trauma. Burn patients require specialized treatment to minimize morbidity and mortality. During the past four decades, management of burns has improved due to advancement in some practices such as fluid resuscitation, proper burn wound care, aseptic techniques employed in managing these patients as well as highly equipped burn centers which has led to a reduction in burns related deaths [1] [2]. Sepsis accounts for $75 \%$ of deaths in burn patients with Total Body Surface Area (TBSA) above 40\% [3] [4] [5] [6] [7]. Debridement, skin grafting and improved infection management and control have led to better outcomes in burn patient management [8] [9]. In some situations, fungal infections may develop later if proper wound management is not implemented [10] [11]. Infections with anaerobes are much likely in the event of electrical burns [12]. Burn management is very costly with an estimated annual economic impact of USD 11.3 billion [13]. Older age, \%Total Body Surface Area and complications of burns such as septicemia, cellulitis, pneumonia, acute respiratory distress syndrome and respiratory failure account for morbidity and mortality [6]. Low socio-economic status, poverty, low educational level, overcrowding and single parenthood all account for increased burn incidence [14]. Often, males are the most affected, as compared to their female counterparts as reported by the National Burn Registry stating that 69.7\% males and 30.3\% females were affected [13]. Most commonly, burns infection is caused by bacteria mostly Pseudomonas aeruginosa. Other rare causing pathogens are yeasts, filamentous fungi and viruses.

\section{Method}

The method adopted in this review article is shown in Figure 1.

\section{Review}

\subsection{Burns and Antibiotics}

Antibiotics are medications that kill bacteria or stop their growth. These medications are obtained from other microorganisms [15]. An antibiotic may be bacteriostatic or bactericidal. An antibiotic may have the ability to inhibit synthesis of bacteria cell wall or inhibit the conversion of glucose to energy and subsequently, the bacteria dies. When antibiotics are effective against a lot of bacteria, they are referred to as Broad-Spectrum Antibiotics and when effective against few bacteria, they are known as Narrow Spectrum Antibiotics [15]. Bacteria can 


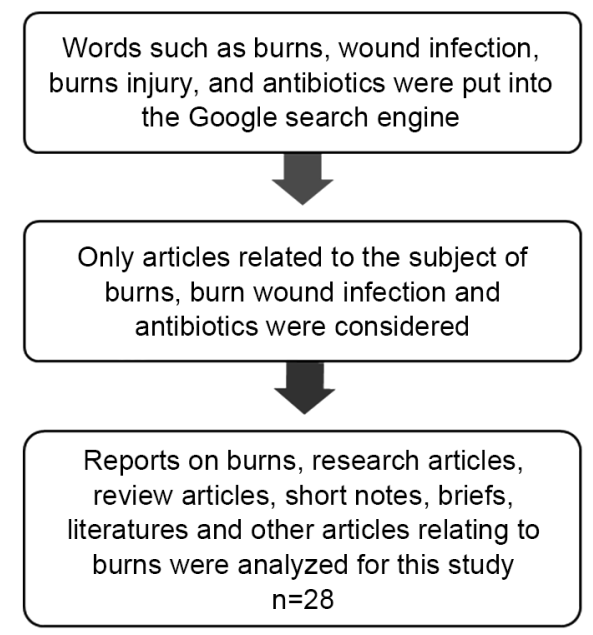

Figure 1. Flow chart of method.

be resistant to antibiotics especially if they are usually exposed to the antibiotics; or develop some form of mechanism that prevents them from being susceptible to the antibiotics [15]. These may be through one of the following: altering their structure and neutralizing the antibiotics; the possibility of transferring gene codes from bacteria which have never been exposed to a particular antibiotic to acquire resistance from bacteria which already have been exposed to the antibiotics and hence these bacteria are shielded [15]. Treating burn patients with wound infection is becoming very difficult especially when resistance to antibiotics sets in. Hence, the use of antibiotics as prophylaxis other than treatment is not advisable as it enhances emergence of resistant organisms.

\subsection{Main Antibiotics Classifications}

The major classification of Antibiotics are listed and expounded on in Table 1.

\section{Discussion}

Introduction or invention of antibiotics, antifungals and topical antimicrobials in the management of burns has played much role in the decrease of mortality and morbidity associated with burns. More so, surgical procedures such as excision and skin grafting have all helped to reduce burn mortality and morbidity and thus increasing survival rate of patients following burn injury.

\subsection{Antibacterial Resistance}

There is the emergence of resistant strains which implies increased hospital stay, economical burden, high morbidity and mortality. For this reason, there is a continual research in providing very good treatment modalities in burns management that will be effective against the emerging resistance strains of bacteria [16]. Cosgrove (2006) reported that patients with pathogens that are resistant to antimicrobials stay longer in hospital than patients with bacteria which are 
Table 1. Classification of antibiotics in burn management.

\begin{tabular}{|c|c|c|}
\hline Burn type & Infectious bacterium & Antibiotics administered \\
\hline \multirow{13}{*}{ All burn types } & \multirow{6}{*}{$\begin{array}{l}\text { a) Gram positive and Gram negative } \\
\text { bacteria strains of staphylococci, } \\
\text { streptococci and meningococcus } \\
\text { b) Some bacterial enzymes that } \\
\text { inactivate natural penicillin } \\
\text { c) Wide range of bacteria [15]. }\end{array}$} & Types of Penicillins \\
\hline & & a) Natural penicillin (Penicillin G class) \\
\hline & & b) Penicillinase resistant penicillins \\
\hline & & (methicillin and oxacillin) \\
\hline & & \multirow{2}{*}{$\begin{array}{l}\text { c) Aminopecillins (ampicillin and } \\
\text { amoxicillin) }\end{array}$} \\
\hline & & \\
\hline & & Cephalosporins \\
\hline & Gram positive bacteria. & First generation cephalosporins \\
\hline & $\begin{array}{l}\text { Gram positives and extend to some } \\
\text { Gram negatives. }\end{array}$ & $\begin{array}{l}\text { Examples are cephradine, cephalexin, } \\
\text { cefazolin and cefalothin; }\end{array}$ \\
\hline & $\begin{array}{l}\text { Most Gram negative bacteria with } \\
\text { some members showing less activity } \\
\text { to Gram positives. }\end{array}$ & $\begin{array}{l}\text { Second generation cephalosporins: } \\
\text { Examples are cefuroxime, cefonicid, } \\
\text { ceforanide and cefamandole; }\end{array}$ \\
\hline & \multirow{3}{*}{$\begin{array}{l}\text { Much Gram positives as first } \\
\text { generation. They show greater } \\
\text { resistance to beta-lactamases than the } \\
\text { third generation. They show much } \\
\text { effectiveness against meningitis. }\end{array}$} & $\begin{array}{l}\text { Third generation cephalosporins } \\
\text { Examples are cefixime, cefetamet, } \\
\text { cefotaxime and ceftriaxone; }\end{array}$ \\
\hline & & Fourth generation cephalosporins: \\
\hline & & $\begin{array}{l}\text { Examples are cefozopran, cefclidine, } \\
\text { cefepime and cefpirome [15]. }\end{array}$ \\
\hline All burn types & $\begin{array}{l}\text { Bacteriostatic, preventing the synthesis } \\
\text { of protein by binding with bacterial } \\
\text { ribosomes. }\end{array}$ & $\begin{array}{l}\text { Macrolides: Examples are azithromycin, } \\
\text { eythromycin, roxithromycin and } \\
\text { dirithromycin }[15] .\end{array}$ \\
\hline All burn types & Gram negative bacteria & $\begin{array}{l}\text { Aminoglycosides: Examples are } \\
\text { gentamicin, amikacin, streptomycin, } \\
\text { tobramycin, kanamycin and neomycin } \\
{[15] .}\end{array}$ \\
\hline All burn types & $\begin{array}{l}\text { These are bactericidal; they work by } \\
\text { preventing bacteria DNA synthesis } \\
\text { hence preventing their multiplication. }\end{array}$ & $\begin{array}{l}\text { Fluoroquinolones: Examples are } \\
\text { ciprofloxacin, ofloxacin, levofloxacin, } \\
\text { norfloxacin and clinafloxacin, etc [15]. }\end{array}$ \\
\hline All burn types & $\begin{array}{l}\text { Both Gram positive and Gram negative } \\
\text { bacteria They are bacteriostatic and } \\
\text { inhibit protein synthesis. }\end{array}$ & $\begin{array}{l}\text { Tetracyclines: Examples are } \\
\text { doxycycline, tetracycline, minocycline } \\
\text { and oxytetracycline [15]. }\end{array}$ \\
\hline
\end{tabular}

highly susceptible to antimicrobials [17]. There is therefore a continual need for the prevention of spread of resistant strains. It is advised that regular antibiotic surveillance should be undertaken at burn centers to guide drug choice if there is indication of infection of the burns wound.

\subsection{Wound Treatment}

Aminoglycosides may be used to treat infections caused by Gram negatives. For some decades now, burn patients are continually being managed properly with application of topical creams (antimicrobials) and timely administration of antibiotics as well and early surgical intervention such as excision and skin grafting. 
All these strategies have contributed to the increasing survival rates of burns victims. Nevertheless, the emergence of resistance of pathogens to antibiotics is a very challenging issue in patients admitted at Burns centers [18].

\subsection{Nosocomial Infections}

Due to the breach in the skin barrier, burns victims are exposed to nosocomial infection. Cross infection is also common, usually caused by the Pseudomonas aeruginosa and Staphylococcus aureus [19]. Hospital acquired infections are also of major concern in persons with burns. These nosocomial infections are attributed with increased length of stay, implying increased costs [20]. Organisms causing nosocomial infections are mostly part of the patients' own normal flora, the environment and healthcare provider [21]. Sterilization of instruments, bed linens, and staff hygiene are steps in preventing infection in burn patients.

Infection of burns may be influenced by age, sex, underlying conditions such as liver or kidney disease, and nutrition [22]. Regular dressing changes and timely surgical intervention helps to reduce length of stay, thereby minimizing cost for the burns patient.

\subsection{Antimicrobials}

Commonly used topical antimicrobials include silver sulphadiazine, silver nitrate solution, silver impregnated dressings and mafenide acetate. Silver sulphadiazine is active against Gram positives and negatives and also shows some activity against Candida [23]. Silver nitrate used at an aqueous concentration of $0.5 \%$ is also effective against Gram positives and negatives and Candida [24]. Mafenide acetate has been reported as having wide antibacterial activity against Staphylococcus and Pseudomonas spp. [25]. Sources of pathogens that are able to infect the burn wounds are from the respiratory and gastrointestinal flora, endogenous and the environment [26]. Good nutrition following burns is advisable since it promotes wound healing. Wound closure does not occur quickly in burns as with other injuries due to a much extended catabolic stage. Hence to promote quick wound healing, much protein intake should be adhered to [27]. Topical application of honey to burn wounds provides a soothing effect. Honey with its antibacterial and antioxidant activity promotes healing of infected deep wounds. It enhances re-epithelialization and quickly decreases the burn wound area [28].

\section{Conclusion}

Burn injury continues to be an issue of major concern in both developing and developed countries with most occurrences in developing countries. Burn wound infection greatly affects its victims often resulting in long periods of hospitalization and rehabilitation. Proper management of burn patients is therefore necessary to ensure their well-being and reduce morbidity and mortality. As 
much as proper management of burns is critical, the role of antibiotics is an issue of major concern. Antibiotics must be administered after culture and sensitivity evidence, in order to reduce the chance of increasing evolution of resistant strains of bacteria.

\section{Acknowledgements}

The authors are grateful to Miss Angelina Effah for extensively editing this manuscript.

\section{References}

[1] Keen, E.F., Robinson, B.J., Hospenthal, D.R., Aldous, W.K., Wolf, S.E., Chung, K.K., et al. (2010) Incidence and Bacteriology of Burn Infections at a Military Burn Center. Burns, 36, 461-468. https://doi.org/10.1016/j.burns.2009.10.012

[2] Lionelli, G., Pickus, E.J., Beckum, O.K., Decoursey, R.L. and Korentager, R.A. (2005) A Three Decade Analysis of Factors Affecting Burn Mortality in the Elderly. Burns, 31, 958-963. https://doi.org/10.1016/j.burns.2005.06.006

[3] Saffle, J.R., Davis, B. and Williams, P. (1995) Recent Outcomes in the Treatment of Burn Injury in the United States: A Report from the American Burn Association Patient Registry. Journal of Burn Care \& Rehabilitation, 16, 219-232. https://doi.org/10.1097/00004630-199505000-00002

[4] Atiyeh, B.S., Gunn, S.W. and Hayek, S.N. (2005) State of the Art in Burn Treatment. World Journal of Surgery, 29, 131-148. https://doi.org/10.1007/s00268-004-1082-2

[5] Baker, C.C., Miller, C.L. and Trunkey, D.D. (1979) Predicting Fatal Sepsis in Burn Patients. Journal of Trauma, 19, 641-648. https://doi.org/10.1097/00005373-197909000-00001

[6] Bang, R.L., Sharma, P.N., Sanyal, S.C. and Al Najjadah, I. (2002) Septicaemia after Burn Injury: A Comparative Study. Burns, 28, 746-751. https://doi.org/10.1016/S0305-4179(02)00183-3

[7] Barrow, R.E., Spies, M., Barrow, L.N. and Herndon, D.N. (2004) Influence of Demographics and Inhalation Injury on Burn Mortality in Children. Burns, 30, 72-77. https://doi.org/10.1016/j.burns.2003.07.003

[8] Fitzwater, J., Purdue, G.F., Hunt, J.L. and O'Keefe, G.E. (2003) The Risk Factors and Time Course of Sepsis and Organ Dysfunction after Burn Trauma. Journal of Trauma, 54, 959-966. https://doi.org/10.1097/01.TA.0000029382.26295.AB

[9] Chung, K.K., et al. (2010) Incidence and bacteriology of burn infections at a military burn center. Burns; 36(4):461-8). https://doi.org/10.1016/j.burns.2009.10.012

[10] Horvath, E.E., Murray, C.K., Vaughan, G.M., Chung, K.K., Hospenthal, D.R., Wade, C.E., et al. (2007) Fungal Wound Infection (Not Colonization) Is Independently Associated with Mortality in Burn Patients. Annals of Surgery, 245, 978-985. https://doi.org/10.1097/01.sla.0000256914.16754.80

[11] Schofield, C.M., Murray, C.K., Horvath, E.E., Cancio, L.C., Kim, S.H., Wolf, S.E., et al. (2007) Correlation of Culture with Histopathology in Fungal Burn Wound Colonization and Infection. Burns, 33, 341-346. https://doi.org/10.1016/j.burns.2006.08.040

[12] Regules, J.A., Carlson, M.D., Wolf, S.E. and Murray, C.K. (2007) Analysis of Anaerobic Blood Cultures in Burned Patients. Burns, 33, 561-564. 
https://doi.org/10.1016/j.burns.2006.10.390

[13] Latenser, B.A., Miller, S.F., Bessey, P.Q., Browning, S.M., Caruso, D.M., Gomez, M., et al. (2007) National Burn Repository 2006: A Ten-Year Review. Journal of Burn Care \& Research, 28, 635-658. https://doi.org/10.1097/BCR.0B013E31814B25B1

[14] Mistry, R.M., Pasisi, L., Chong, S., Stewart, J. and She, R.B. (2010) Socioeconomic Deprivation and Burns. Burns, 36, 403-408. https://doi.org/10.1016/j.burns.2009.05.021

[15] Antibiotics. www.emedexpert.com/classes/antibiotics.shtml

[16] Dai, T., Huang, Y.Y., Sharma, S.K., Hashmi, J.T., Kurup, D.B. and Hamblin, M.R. (2010) Topical Antimicrobials for Burn Wound Infections. Recent Patents on AntiInfective Drug Discovery, 5, 124-151. https://doi.org/10.2174/157489110791233522

[17] Cosgrove, S.E. (2006) The Relationship between Antimicrobial Resistance and Patient Outcomes: Mortality, Length of Hospital Stay, and Health Care Costs. Clinical Infectious Diseases, 42, S82-S89. https://doi.org/10.1086/499406

[18] Sharma, B.R. (2007) Infection in Patients with Severe BURNS: causes and Prevention Thereof. Infectious Disease Clinics of North America, 21, 745-759. https://doi.org/10.1016/j.idc.2007.06.003

[19] Gupta, M., Gupta, O.K., Yaduvansh, R.K. and Upadhyahy, J. (1993) Burn Epidemiology: The Pink City Scene. Burns, 19, 47-51. https://doi.org/10.1016/0305-4179(93)90100-M

[20] Craven, D.E., Steger, K.A. and Barber, T.W. (1991) Preventing Nosocomial Pneumonia: State of the Art and Perspectives for the 1990s. American Journal of Medicine, 91, 44S-53S. https://doi.org/10.1016/0002-9343(91)90343-V

[21] Heggers, J., Linares, H.A., Edgar, P., Vilareal, C. and Hendron, D.N. (2001) Treatment of Infections in Burns. In: Hendron, D.N., Ed., Total Burn Care, WB Saunders, Philadelphia, PA.

[22] Moyer, C.A., Brentano, L., Gravens, D.L., et al. (1965) Treatment of Large Burns with $0.5 \%$ Silver Nitrate Solution. Archives of Surgery, 90, 812-814. https://doi.org/10.1001/archsurg.1965.01320120014002

[23] Hern, T.T., Rosliza, A.R., Siew, H.G., Ahmad, S.H., Siti, A.H., Siti, A.S. and KirnpalKaur, B.S. (2009) The Antibacterial Properties of Malaysian Tualang Honey. BMC Complementary and Alternative Medicine, 9, 1-8.

[24] Thompson, P.D., Taddonio, T.E., Tait, M.J., et al. (1989) Susceptibility of Pseudomonas and Staphylococcus Wound Isolates to Topical Antimicrobial Agents: A 10-Year Review and Clinical Evaluation. Burns, 15, 190-192. https://doi.org/10.1016/0305-4179(89)90181-2

[25] Ahmed, A.K., Hoekstra, M.J., Hage, J. and Karim, R.B. (2003) Honey-Medicated Dressing: Transformation of an Ancient Remedy into Modern Therapy. Annals of Plastic Surgery, 50, 143-148. https://doi.org/10.1097/01.SAP.0000032306.44107.C1

[26] Tiwari, V.K. (2012) Burn Wound: How It Differs from Other Wounds? Indian Journal of Plastic Surgery, 45, 364-373. https://doi.org/10.4103/0970-0358.101319

[27] Shupp, J.W., Nasabzadeh, T.J., Rosenthal, D.S., Jordan, M.H., Fidler, P. and Jeng, J.C. (2010) A Review of the Local Pathophysiologic Bases of Burn Wound Progression. Journal of Burn Care \& Research, 31, 849-873. https://doi.org/10.1097/BCR.0b013e3181f93571

[28] Nisbet, H.O., Nisbet, C., Yarim, M., Guler, A. and Ozak, A. (2010) Effects of Three Types of Honey on Cutaneous Wound Healing. Wounds, 22, 275-283. 
Submit or recommend next manuscript to SCIRP and we will provide best service for you:

Accepting pre-submission inquiries through Email, Facebook, LinkedIn, Twitter, etc. A wide selection of journals (inclusive of 9 subjects, more than 200 journals)

Providing 24-hour high-quality service

User-friendly online submission system

Fair and swift peer-review system

Efficient typesetting and proofreading procedure

Display of the result of downloads and visits, as well as the number of cited articles

Maximum dissemination of your research work

Submit your manuscript at: http://papersubmission.scirp.org/

Or contact ss@scirp.org 